\title{
УЧАСТЬ МЕДСЕСТРИ У ФОРМУВАННІ КОМПЛАЄНСУ ДО ЛІКУВАННЯ ПАЦІЄНТІВ ІЗ ГІПЕРТОНІЧНОЮ ХВОРОБОЮ ТА ІШЕМІЧНОЮ ХВОРОБОЮ СЕРЦЯ
}

\author{
А. І. Смачило, Г. С. Сивак, О. В. Камінська, I. І. Паньків \\ ДВНЗ «Тернопільський державний медичний університет \\ імені I. Я. Горбачевського МОЗ Украӥни»
}

У статті розглянуто актуальні питання формування комплаєнсу (прихильності) до лікування пацієнтів із гіпертонічною хворобою та ішемічною хворобою серця. Оцінено необхідність взаємодії медичних сестер і пацієнтів при вирішенні проблем, пов’язаних із недостатнім комплаєнсом до проведеної медикаментозної терапії.

\section{THE PARTICIPATION OF A NURSE IN FORMATION OF COMPLIANCE TO TREATMENT OF PATIENTS WITH HYPERTENSIVE DISEASE AND ISCHEMIC HEART DISEASE}

\section{A. I. Smachylo, H. S. Syvac, O. V. Kaminskaya, I. I. Pankiv \\ I. Horbachevsky Ternopil State Medical University}

\begin{abstract}
The article deals with pressing issues of formation of compliance to the treatment of patients with hypertensive disease (HD) and ischemic heart disease (IHD). The necessity of interaction of nurses and patients in solving of problems connected with insufficient compliance to the conducted medical treatment is assessed.
\end{abstract}

Вступ. Гіпертонічна хвороба (ГХ) та ішемічна хвороба серця (IXC) залишаються однією з головних проблем охорони здоров'я в усьому світі, а пошук шляхів підвищення ефективності їх лікування, спрямованих на зниження ускладнень та смертності, є актуальним завданням [1]. Як відомо, з 1 квітня 2017 р. в Україні діє урядова програма «Доступні ліки», у рамках якої пацієнти за рецептом лікаря можуть отримати безкоштовно або з доплатою лікарські засоби для лікування серцево-судинних захворювань, цукрового діабету 2 типу та бронхіальної астми. Наказом МОз України від 03.08.2018 р. № 1446 значно розширено перелік лікарських засобів для лікування артеріальної гіпертензії та IXC [2]. Проте великою психологічною проблемою для цієї категорії хворих залишається необхідність пожиттєвого регулярного приймання ліків та медичного спостереження. Низька інформованість у питаннях лікування та профілактики захворювання негативно впливає на комплаєнс пацієнта. Час, відведений для лікаря на амбулаторний прийом, і спілкування з пацієнтом обмежені, за кілька хвилин

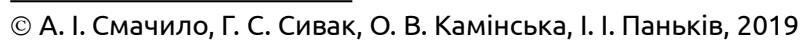

важко оцінити прихильність пацієнта до постійного лікування. Активним помічником лікаря у цьому випадку стає медична сестра. Посилення взаємодії хворого і медсестри - шлях до вирішення проблеми формування у нього комплаєнсу до лікування.

Мета роботи - оцінити необхідність взаємодії медичних сестер і пацієнтів при вирішенні проблем, пов'язаних із недостатнім комплаєнсом (прихильністю) пацієнтів до проведеної медикаментозної терапії, що в медичному розумінні означає готовність, бажання хворого виконувати лікарські рекомендації щодо регулярного приймання лікарських препаратів, дотримання графіка візитів до лікаря, дієти, фізичного навантаження та інших змін способу життя.

Основна частина. У дослідження було включено дві групи пацієнтів із ГX та IXC, які отримували загальноприйняту терапію, згідно з положеннями рекомендацій лікування Європейського товариства кардіологів (ESC) 2018 р. На початку, через 1 та 2 місяці спостереження, усім пацієнтам проводили загальноклінічне дослідження, рекомендували вести щоденники самоконтролю артеріального тиску (АТ). Його 
вимірювали після 3-хвилинного відпочинку, сидячи, на правій руці.

Пацієнтам першої групи (48 осіб, 23 жінки та 25 чоловіків) проводили стандартний амбулаторний моніторинг артеріального тиску з періодичними оглядами у первинному центрі медико-санітарної медичної допомоги, а також застосовували метод телефонного нагадування щодо необхідності регулярного приймання ліків (у перший тиждень спостереження - через день, в наступні 3 тижні - 2 рази на тиждень, у подальшому - протягом 2 місяців - один раз щотижня). Також хворим видавали «Пам'ятку пацієнта» з рекомендаціями правил правильного харчування, режиму динамічного фізичного навантаження, ведення щоденника самоконтролю гемодинамічних показників. Пацієнтам другої групи (54 особи, 26 жінок та 28 чоловіків) телефонні нагадування не проводили. В іншому - частота візитів до лікаря, видача «Пам'ятки пацієнта» були однаковими у пацієнтів обох груп. Усім пацієнтам рекомендували ведення щоденника самоконтролю, який був розроблений спеціально для цього дослідження, 3 визначенням показників артеріального тиску і пульсу (щоденно), періодично - маси, постійно приймаючи рекомендовані медичні препарати.

Прихильність до терапії оцінювали за допомогою спеціалізованого опитувальника Моріски-Гріна, який валідизований і рекомендований до широкого застосування [3]. Це найпростіший тест оцінки прихильності до терапії. Він складається з 4 питань: 1) чи забували Ви коли-небудь приймати препарати? (так - 0, ні - 1); 2) чи відноситесь Ви іноді неуважно до часу приймання ліків? (так - 0, ні - 1); 3) чи пропускаєте Ви приймання препаратів, якщо почуваєте себе добре? (так - 0, не пропускаю - 1); 4) якщо Ви почуваєте себе погано після приймання ліків, то чи не пропускаєте Ви наступне приймання? (так - 0, ні - 1). Пацієнт повинен самостійно відповідати на запитання, вибираючи один із 2 варіантів відповідей. Кожну відповідь оцінюють по 1 балу. При обробці підраховують сумарний бал. Прихильним до терапії вважається пацієнт, який відповів «ні» на всі 4 питання. Хворі, які набрали 3 бали, вважаються недостатньо прихильними і перебувають у групі ризику по розвитку нонкомплаєнсу. Хворі, які набрали 2 бали і менше, вважаються неприхильними до лікування. Цей метод дозволяє оцінити вихідну прихильність пацієнтів, а також динаміку цього показника у процесі дослідження.

Виявлено, що на початку дослідження, за результатами проведеного опитування, прихильними до лікування були лише 5 \% пацієнтів, неприхильними - $29 \%$.
Решту 66 \% обстежених - були недостатньо прихильними і перебували у групі ризику по нонкомплаєнсу. Співвідношення прихильних до лікування та неприхильних і недостатньо прихильних становило 1:7, що вказує на серйозну існуючу проблему лікарської терапії, яка вимагає втручання як з боку лікарів, так і з боку медичних сестер.

Оцінка динаміки комплаєнсу до терапії, на початку дослідження, через 1 та 2 місяці показала, що кількість прихильних до терапії пацієнтів збільшилася як у групі з телефонним нагадуванням (з 13 до 57 \%), так і в групі пацієнтів без нагадування (з 11 до 28 \%). Аналіз балів за тестом Моріски-Гріна показав, що комплаєнс у першій групі мав значно кращу динаміку.

На антигіпертензивну терапію відповіли усі пацієнти. Цільовий рівень АТ (за класифікацією ВООЗ $<140 / 90$ мм рт. ст.) був досягнутий у $77 \%$ пацієнтів першої групи та 59 \% у пацієнтів другої групи. Наприкінці усього періоду спостереження відзначено достовірне зниження рівня АТ у обох групах, однак ступінь зниження був більш вираженим у пацієнтів першої групи.

Через 2 місяці терапії зареєстровано достовірне зниження середньодобового САТ і ДАТ за рахунок дії препаратів (рис. 1, 2).

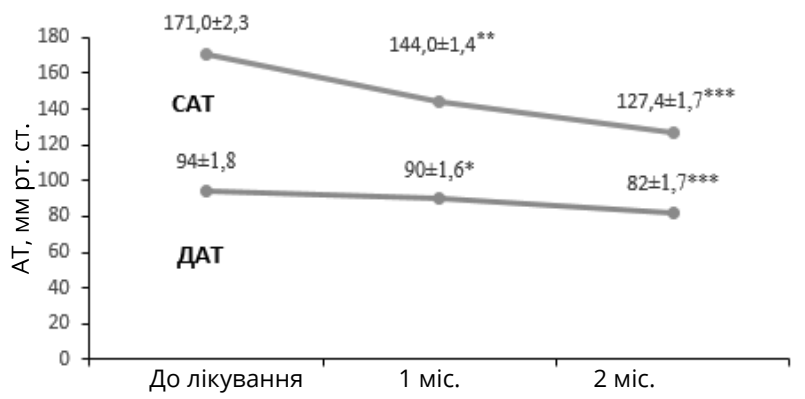

Примітки: * $-p<0,005 ; * *-p<0,02 ; * * *-p<0,001$.

РUс. 1. Динаміка офісного артеріального тиску протягом 2 місяців лікування пацієнтів першої групи.

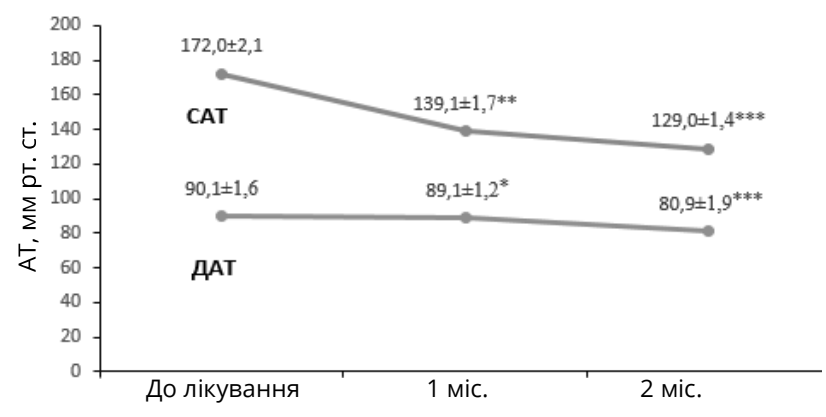

Примітки: * - $<<0,005 ; * *-p<0,02 ; * * *-p<0,001$.

PUC. 2. Динаміка офісного артеріального тиску протягом 2 місяців лікування пацієнтів другої групи. 
Пацієнти, яким проводили телефонне нагадування, ретельніше вели щоденник самоконтролю, більшість з них відзначала, що такі нагадування їм значно допомагають психологічно.

Отже, отримані дані дослідження дозволяють зробити висновок про те, що застосування телефонних нагадувань дозволяє достовірно підвищити прихильність до терапії у пацієнтів із ГX та IXC. Необхідно відзначити, що серед пацієнтів, яким проводили телефонні нагадування, частка осіб, які вели щоденники самоконтролю, була вищою.

Висновки. 1. Основна частка пацієнтів із ГX та IXC не прихильна до лікування, що істотно підвищує загрозу тяжких наслідків.

\section{СПИСОК ЛІТЕРАТУРИ}

1. $2013 \mathrm{ESH} / \mathrm{ESC}$ Guidelines for the management of arterial hypertension: 234 The Task Force for the management of arterial hypertension of the European Society of Hypertension (ESH) and of the European Society of Cardiology (ESC) // Eur. Heart J. - 2013. - Vol. 34. - P. 2159-2219.

2. dn_20180803_1446 (pdf, 51 K6)

3. Morisky D. E. Concurrent and predictive validity of a selfreported measure of medication adherence / D. E. Morisky,
2. Існує необхідність налагодити роботу сестринського персоналу з пацієнтами для діагностики і корекції нонкомплаєнсу.

3. Комбінація застосування телефонних нагадувань і використання щоденників самоконтролю дозволяє домогтися комплаєнсу до лікування у спостережуваних.

4. Формування комплаєнсу хворого $є$ багатофакторним процесом, важливим з яких $є$, окрім удосконалення процесу лікування, вплив лікаря та медсестри на хворого.

L. W. Green, D. M. Levine // Med. Care. - 1986. - Vol. 24. P. 67-74.

4. Carter S. A question of choice - compliance in medicine taking, a preliminary review/S. Carter, D. Taylor, R. Levenson. London: University of London School of pharmacy, 2001. - Mode access : www.medicinespartnership. org Accessed 04 Dec 2012. 